\author{
St ud i P hilos o p hi c a \\ Wr a t i s l a vi e n s i a \\ vol. XIII, fasc. 4 (2018) \\ DOI: $10.19195 / 1895-8001.13 .4 .1$
}

JACEK JADACKI
Uniwersytet Warszawski

\title{
Wkład Kazimierza Twardowskiego w rozwój logiki w Polsce
}

Opublikowana dotąd spuścizna Twardowskiego — i jej szczegółowy rozbiór — wystarcza, by wolno było uważać go za klasyka semiotyki polskiej. Do najważniejszych rezultatów w dziedzinie semiotyki należą jego dystynkcje w obrębie funkcji semiotycznych oznak (na przykład odróżnienie bycia-wyrazem od wyrażania), funkcji askrypcyjnej znaków językowych (na przykład uzupełnienie listy tych funkcji w wypadku przymiotników - o funkcję abolującą i konfirmującą), funkcji modyfikacyjnej spójników (na przykład spójnika „nie” w kontekstach nominalnych), a także argumentacja na rzecz stanowiska w sprawie funkcji referencyjnej nazw, zgodnie z którym każda nazwa odnosi się do jakiegoś przedmiotu (a zatem nie ma nazw pustych). Swoje poglądy semiotyczne oparł Twardowski na oryginalnej bazie metafizycznej — przede wszystkim na idiogenicznej koncepcji sądów (zakładającej redukowalność wszelkich sądów do sądów egzystencjalnych) i transeuntnej koncepcji ich prawdziwości (zgodnie z którą polega ona na zgodności między jakością sądu a jego przedmiotem ze względu na osnowę).

Na wysoką ocenę zasługują też opublikowane rezultaty Twardowskiego w dziedzinie metodologii, przede wszystkim nowe ujęcie klasyfikacji nauk (na przykład ich podziału na nauki dedukcyjne i indukcyjne), analiza relacji między różnymi dyscyplinami naukowymi (na przykład między filozofią i logiką a gramatyką, psychologią i fizjologią) i docenienie badań interdyscyplinarnych (które sam z powodzeniem prowadził).

$$
* * *
$$

Nowe światło na wkład Twardowskiego w rozwój logiki w Polsce rzuca zawartość jego jeszcze nieopublikowanej spuścizny, a wśród niej treść prowadzonych przez niego wykładów z logiki i niewydanych monografii logicznych. 
Okazuje się, po pierwsze, że Twardowski prowadził owocne badania nad wieloma problemami metodologicznymi. Efektem tych badań było — nieznane dotąd szerszej publiczności — ujęcie teorii indukcji i określenie perspektyw metody indukcyjnej w metafizyce, pierwsza w naszej literaturze tak obszerna monografia na temat rozumowań oraz rekonstrukcja pojęcia rozumienia.

Po drugie, Twardowski nawiązywał w swoich nieopublikowanych dotąd wykładach i monografiach do ważnych wyników dziewiętnastowiecznej logiki formalnej (między innymi Boole'a, Jevonsa, Perce'a i Schrödera), dajacc tym samym swoim uczniom impuls do indywidualnych badań w tej dziedzinie; poddał też wnikliwej krytyce Brentanowską reformę sylogistyki i przedstawił własną propozycję takiej reformy; przy okazji sformułował także kryteria adekwatności symbolizmu logicznego.

$$
* * *
$$

Rezultaty Twardowskiego z zakresu szeroko pojętej logiki, zawarte w jego opublikowanych tekstach, poddałem analizie i krytyce w ogólnie dostępnych monografiach. Tutaj skupię się na kwestiach logicznych poruszanych przez Twardowskiego $\mathrm{w}$ tekstach jeszcze nieopublikowanych ${ }^{*}$.

\section{Koncepcja logiki}

Twardowski w swych niedatowanych wykładach z logiki rozróżnił dwa sensy „prawdy” (resp. „mówienia prawdy”). Nazwijmy je odpowiednio „sensem semantycznym" i ,sensem pragmatycznym”. Rozróżnienie Twardowskiego wolno zrekonstruować tak:

(1) Jeżeli powiedzenie $\alpha$ stwierdza zachodzenie stanu rzeczy $S$, to: powiedzenie $\alpha$ jest PRAWDĄ w sensie semantycznym (scil. jest powiedzeniem prawdziwym), gdy stan rzeczy $S$ w rzeczywistości zachodzi.

(2) Jeżeli powiedzenie $\alpha$ wyraża przekonanie $P$, to: powiedzenie $\alpha$ przez osobę $O$ jest PRAWDA $\mathrm{w}$ sensie pragmatycznym (scil. jest powiedzeniem szczerym), gdy osoba $O$ rzeczywiście żywi przekonanie $P$.

Jeżeli stan rzeczy, o którym mowa w (1), nie zachodzi w rzeczywistości, to powiedzenie stwierdzające jego zachodzenie jest MYLNE; jeżeli osoba, o której mowa w (2), nie żywi przekonania wyrażanego przez umyślnie przez nią użyte powiedzenie, to osoba ta KŁAMIE.

Z (1) i (2) widać, że nie każde powiedzenie daje się określić pod względem prawdy i mylności oraz szczerości i kłamliwości. Warunek ten spełniają tylko powiedzenia, za pomoca których można coś stwierdzić lub wyrazić, a więc zdania (w sensie logicznym).

* Tekst powstał w ramach projektu 2016/23/B/HS1/00684 „Miejsce Kazimierza Twardowskiego w kulturze polskiej i filozofii europejskiej", finansowanego przez Narodowe Centrum Nauki. 
Twardowski zwrócił uwagę na to, że jeżeli prawdziwe lub mylne są jakieś powiedzenia, to również przekonania (resp. sacdy) wyrażane przez te powiedzenia są — odpowiednio - prawdziwe lub mylne. Przenośnie można również mówić o prawdziwości lub mylności przedstawień. W szczególności:

(3) Przedstawienie przedmiotu $Q$ takie, że $Q$ jest $R$, jest prawdziwe (w sensie przenośnym), gdy przekonanie, że $Q$ jest $R$, jest prawdziwe (w sensie pierwotnym).

Po tych wstępnych ustaleniach Twardowski tak określił logikę:

Logika jest nauką, która nam podaje sposoby odróżniania przekonań prawdziwych od mylnych; jest więc logika nauką o warunkach prawdziwości sądów - lub pokrótce: nauką o prawdziwości sądów.

\section{Symbolizm logiczny}

Znany artykuł Twardowskiego Symbolomania i pragmatofobia ${ }^{1}$ z 1921 roku został przez niektórych odebrany jako zawoalowana krytyka logiki symbolicznej jako takiej. Jest to interpretacja mylna; dostrzeże to każdy uważny czytelnik tego artykułu. Właściwe intencje Twardowskiego w tym zakresie można znaleźć w nieopublikowanym tekście Symbolizm logiczny, napisanym nie później niż w 1917 roku, którego główną ideę tutaj przedstawię.

Otóż według Twardowskiego systemy logiczne powinny być teoriami faktycznie przez nas przeprowadzanych rozumowań, a w szczególności procesów wnioskowania i sprawdzania ich poprawności. Jeśli do pełnienia takiej funkcji nie pretendują - lub pretendujac, ale nie udaje się im tego osiągnąć — narażają się na zarzut ,jednostronnego i suchego formalizmu".

Przytoczmy in extenso, jakie postulaty sformułował Twardowski wobec systemów logicznych, ,stojących na wysokości zadania”, a więc wolnych od wspomnianego zarzutu:

(1) [System logiczny nie powinien] przesądzać nic o tym, jakie są kategorie sądów i nie zmuszać do sprowadzania wszystkich sądów do pewnych tylko form. Każdy sąd musi wejść w skład rozumowania jak najściślej, ale zarazem najzgodniej z duchem dotyczącego [to jest odpowiedniego] języka da się wyrazić. Dziwolągi językowe utrudniają zbadanie wnioskowania.

(2) [System logiczny] musi być wolny od reguł i prawideł, których wyuczenie się i zastosowanie wymaga osobnej wprawy. Wszak to się zapomina, a potem jak sprawdzać?

(3) [System logiczny] musi odpowiadać istocie wnioskowania, a nie podstawiać pod nie jakieś inne operacje, które w najlepszym razie są tylko pewną odosobnioną formą wnioskowania.

Niestosowanie się do tych właśnie postulatów sprawia, że dany system jest NIEADEKWATNY: charakteryzuje go deficyt kategorii gramatycznych, sztuczność reguł ewaluacji i deformacja operacji inferencyjnych. Takie było źródło niechęci Twardowskiego do symbolomanii i pragmatofobii, których symptomy dostrzegał między innymi u niektórych ze swych uczniów.

${ }^{1}$ Zob. K. Twardowski, Symbolomania i pragmatofobia (1921), [w:] idem, Wybrane pisma filozoficzne, Warszawa 1965, s. 354-363. 


\section{Logika tradycyjna i algebraiczna}

Reforma tradycyjnej logiki grecko-scholastycznej została zapoczątkowana pod hasłem uwolnienia tej logiki od wskazanej nieadekwatności kategorialnej, ewaluacyjnej i inferencyjnej. Tymczasem, według Twardowskiego, również nowsze systemy logiki - mimo subtelniejszego rozróżnienia „pewnych form logicznego myślenia” — narażone są na ten sam zarzut nieadekwatności. Dotyczy to w szczególności logiki algebraicznej Boole'a, Jevonsa, Peirce'a, Schrödera i Hontheima. Wszystkie te systemy łączy z logiką tradycyjną to, że struktury, do których sprowadzone zostają sądy faktyczne, przedstawiane są w nich w sposób symboliczny.

A. Nieadekwatność kategorialna - i w logice tradycyjnej, i w logice algebraicznej — przejawia się w tym, że sądy faktyczne, to jest występujące w faktycznym rozumowaniu, zostają $\mathrm{w}$ tych systemach sprowadzone do preferowanych w nich struktur; w szczególności ujednolicone kategorialnie zostaja (a) terminy zawarte $\mathrm{w}$ tych sądach i (b) relacje między tymi terminami.

Dla logiki tradycyjnej — Twardowski ilustruje to na przykładzie rozumowań, w których występują wyłącznie sądy kategoryczne. W sylogistyce sądów kategorycznych wszelkie terminy sprowadza się do tak zwanych terminów większych $(S)$, średnich $(M)$ i mniejszych $(P)$, a wszelkie relacje między terminami - do relacji wyrażanej za pomocą słów „,jest” (resp. „są”) lub „nie jest” (resp. „nie są”). W konsekwencji wszelkie sądy kategoryczne przyjmują postać: SaP, SiP, SeP lub SoP. Natomiast w logice algebraicznej — w szczególności w systemie Jevonsa (który Twardowski dokładniej analizuje) — używa się jedynie terminów pozytywnych $S$ lub $P$, i negatywnych $s$ lub $p$, odczytywanych jako: nie- $S$ lub (odpowiednio) nie- $P$, a wszelkie relacje między desygnatami lub denotacjami terminów zostają zastąpione relacją identyczności. Ponieważ są trzy odmiany identyczności: zupełna, częściowa i ograniczona, wszelkie twierdzące sądy kategoryczne sprowadza się tutaj do sądów o postaci: $S=P$ (identyczność zupełna), $S=S P$ (identyczność częściowa) i $S T=S P T$ (identyczność ograniczona); przeczące zaś sądy kategoryczne - do sądów o postaci: $S=p, S=S p$ i $S T=S p T$.

Faktyczne struktury sądów, nad którymi odbywają się rzeczywiste rozumowania, dadzą się zinterpretować w proponowanych w tych logikach strukturach kategorialnych jedynie w sposób bardzo „sztuczny”. Dotyczy to zwłaszcza sądów relacyjnych (porównaj na przykład: „Londyn — jest-stolicą — Anglii”), sądów bezpodmiotowych (porównaj na przykład: „Dnieje”) oraz sądów w rodzaju: „Kto nic nie uznaje, ten wszystkiemu zaprzecza".

B. Logika tradycyjna i algebraiczna są nieadekwatne ewaluacyjnie, gdyż ich reguły oceny nie wystarczają, aby skontrolować prawidłowość wielu rodzajów wnioskowań (porównaj na przykład wnioskowanie w rodzaju: „Skoro to, co się nie składa z części, nie może być zniszczone przez rozkład na części, a dusza nie składa się z części, to dusza nie może być zniszczona przez rozkład na części” i wszelkie wnioskowania entymematyczne w rodzaju: „Skoro Kraków jest największym miastem w Galicji Zachodniej, a Lwów w Galicji, to Lwów jest większy aniżeli Kraków"). Poza tym kontrola prawidłowości rozumowania wymaga niekiedy dokonania czynności, które od wspomnianych reguł są całkiem niezależne (porównaj na przykład błąd 
quaternio terminorum, mający swe źródło w dwuznaczności wyrazów, która przed ewaluacją musi zostać odzwierciedlona w schematach wchodzących w grę sądów).

C. Faktyczny proces rozumowania w logice tradycyjnej sprowadzony jest do manipulowania schematami sądów kategorycznych, określonego przez odpowiednie tryby i figury; natomiast w logice algebraicznej Jevonsa - sprowadzony jest do mechanicznej operacji podstawiania, dokonywanej na symbolach występujących w jej schematach. Formuły logiki tradycyjnej i algebraicznej nie wyczerpuja wszystkich faktycznie zdarzających się form wnioskowania (porównaj na przykład „Skoro nie ma duchów widzialnych i nie ma duchów niewidzialnych, to nie ma w ogóle - duchów").

\section{Brentanowska reforma sylogistyki}

W tym samym tekście — Symbolizm logiczny — a także w późniejszej (napisanej nie wcześniej niż w 1924 roku) niedokończonej i nieopublikowanej pracy o swoim mistrzu, Brentanie, Twardowski zanalizował Brentanowską reformę sylogistyki.

Główne założenia swojej reformy Brentano, wyłożył w wykładach z roku 1870/1871, które prowadził w Uniwersytecie Wiedeńskim. Impulsem do tej reformy była Brentanowska koncepcja sądów. Zgodnie z tą koncepcją sądzenie polega na uznawaniu (scil. stwierdzaniu) lub odrzucaniu (scil. zaprzeczaniu) istnienia jakiegoś przedmiotu. W tym duchu Brentano - idąc zresztą śladami Bolzana zinterpretował sądy kategoryczne. W jego symbolice: znak '+' był symbolem sądu twierdzącego, znak '-' — symbolem sądu przeczącego, natomiast znaki ' $s$ ' i ' $p$ ' — symbolami kolejno non- $S$ i non- $P$. W ten sposób zapis egzystencjalnej interpretacji sądów kategorycznych wyglądał u Brentana następująco:

$S$ a $P \leftrightarrow_{\text {def. }}+S$ i $-S p$ (Istnieją $S$ i nie istnieją $S$ niebędące $P$ ),

$S$ i $P \leftrightarrow_{\text {def. }}+S P($ Istnieją $S$ będące $P)$,

$S$ e $P \leftrightarrow \leftrightarrow_{\text {def. }}+S$ i $-S P$ (Istnieją $S$ i nie istnieją $S$ będące $P$ ),

$S$ o $P \leftrightarrow \leftrightarrow_{\text {def. }}+S p$ (Istnieją $S$ niebędące $P$ ).

Mimo rewerencji, z jaką Twardowski odnosił się do swego mistrza, także wobec Brentanowskiego systemu logicznego wysuną podobne zarzuty co wobec logiki tradycyjnej i logiki algebraicznej. Uważał w szczególności, że przykłady ewaluacyjnej oraz inferencyjnej nieadekwatności logiki algebraicznej dotyczą również systemu Brentanowskiego. Natomiast jako ilustrację jego nieadekwatności kategorialnej wskazał konieczność uznania na jego gruncie sądu typu „Każdy człowiek jest śmiertelny", a więc ewidentnie twierdzącego sądu prostego, za sąd złożony z członem przeczącym, a mianowicie za koniunkcję sądów „Istnieją ludzie” i „Nie istnieją ludzie nieśmiertelni".

\section{Adekwatny system logiczny}

Twardowski nie ograniczył się do wytknięcia nieadekwatności istniejącym systemom logiki formalnej, ale scharakteryzował w Symbolizmie logicznym system, który od zarzutu adekwatności byłby wolny. 
Wnioskowanie polega na tym, by przekonać się, jakie sądy z innych wynikają. To jest stosunek zależności logicznej: [stosunek] racja-następstwo.

Jeżeli z jakiegoś sądu wynika drugi sąd, to pierwszy jest racją $(R)$ drugiego, a drugi jest następstwem $(N)$ pierwszego. „Na dnie” każdego wnioskowania znajdujemy — według Twardowskiego — następującą ogólną zasadę rozumowania:

Jeżeli prawdą [jest] $R$, wtedy też musi być prawdą $N$.

Dalej czytamy u Twardowskiego:

Ta zasada ogólna rozumowania rozpada się w praktyce na tysiączne formy konkretne.

[1] Jeżeli prawdą jest, że pewien przedmiot nigdy nie posiada pewnej cechy, wtedy też prawdą być musi, że przedmioty posiadające ową cechę, nie są tamtymi przedmiotami. [...]

[2] Jeżeli prawdą [jest], że przedmioty $R$ posiadają cechę $\dot{z}$, a przedmioty $W$ nie posiadają cechy $\dot{z}$, wtedy też musi być prawdą, że przedmioty $W$ nie są przedmiotami $R$.

Więc teoria logiki ma [za] zadanie wyszukać te wszystkie cechy w możliwym komplecie i ugrupować je.

Niestety — z niewiadomych dla mnie powodów — do zbudowania przez Twardowskiego tak scharakteryzowanego systemu logicznego nie doszło. (Rękopis Symbolizmu logicznego pozostał niedokończony). Lista ,form konkretnych wnioskowania" zamknęła się na wskazanych dwóch pozycjach.

\section{Dyscypliny aprioryczne i empiryczne}

Analizę tradycyjnego podziału dyscyplin naukowych na dyscypliny aprioryczne i empiryczne Twardowski poprzedził odróżnieniem „,zynności prowadzących do wykrycia [...] sądów” naukowych od „czynności służących do ich sprawdzenia, czyli uzasadnienia". Mówił przy tym o wykrywaniu i uzasadnianiu sądów, a nie faktów, gdyż nie wszystkie dyscypliny dotyczą faktów (nie dotyczy faktów na przykład matematyka), a poza tym nie fakty wymagają uzasadnienia, lecz sądy odnoszące się do faktów. Odróżnienie wykrywania i uzasadniania sądów rzuca „jasne światło" na relację między badaniem naukowym a doświadczeniem. Inną bowiem sprawą jest obecność doświadczenia w wykrywaniu sądów, a inną w ich uzasadnianiu.

Wiele lat później rozróżnienie to spopularyzował, jak wiadomo, Popper $^{2}$.

Podział nauk na empiryczne i aprioryczne z perspektywy uzasadniania sądów nie budzi wątpliwości. Nauki (jak na przykład astronomia), w których uzasadnia się należące do nich twierdzenia przez odwołanie się do doświadczenia, to nauki empiryczne; nauki (jak na przykład matematyka, logika), których twierdzenia uzasadnia się niezależnie od doświadczenia, gdyż twierdzenia te stanowią „określenia pojęć” i „pewniki, wynikające z logiczną koniecznością z owych określeń” — to nauki aprioryczne.

Inaczej jest z podziałem nauk z perspektywy uzasadniania sądów, który ,znika", kiedy przyjmie się perspektywę wykrywania sądów. Chodzi o to, że zarówno w dyscyplinach empirycznych, jak i apriorycznych dochodzić do sądów można na podstawie doświadczenia lub bez niego („drogą rozumowania” lub „genialnej

${ }^{2}$ Zob. K. Popper, Logik der Forschung, Wien 1935.

Studia Philosophica Wratislaviensia 13, 2018 z. 4, (C) for this edition by CNS 
intuicji”); podobnie też w obu typach dyscyplin doświadczenie jest „ostatecznym źródłem wszystkich pojęć [...], którymi te nauki operują i które wchodzą w skład ich twierdzeń".

\section{Metoda dedukcyjna}

Czym dla nauk empirycznych jest doświadczenie, tym dla nauk apriorycznych jest rozumowanie. Zarówno wyraz „doświadczenie” (i pochodne), jak i wyraz „rozumowanie", jeśli mają wyznaczać te dwa typy dyscyplin naukowych, muszą mieć precyzyjny sens. Twardowski pojęcie doświadczenia poddał precyzacji w artykule opublikowanym w $1912 \mathrm{roku}^{3}$. Natomiast pojęcie rozumowania uczynił przedmiotem analizy w niepublikowanym tekście O pojęciu rozumowania z około 1915 roku.

Stwierdziwszy w nim, że wyraz ,rozumowanie” nie ma w polszczyźnie (a jego odpowiedniki — w innych językach) ustalonego sensu, Twardowski postawił sobie za cel właśnie ustalenie jego sensu, czyli terminologizację tego wyrazu. Przy okazji sformułował następującą dyrektywę metodologiczną dotyczącą tworzenia terminologii:

Rozporządzając wyrazem o znaczeniu dotąd nieustalonym, najlepiej przeznaczyć go - ile możności w sposób niezbyt odbiegający od potocznego sposobu mówienia - na oznaczenie czegoś, co dotąd nazwy ustalonej nie posiada.

Terminologizacja ma przy tym — w ujęciu Twardowskiego — trzy etapy: (1) ustalenie genus proximum; (2) ustalenie denotacji (przez wyliczenie jej podzbiorów właściwych); (3) ustalenie konotacji — Twardowski mówi tutaj o podaniu kryterium bycia elementem denotacji. Genus proximum dla rozumowania jest: operacja czysto logiczna. Denotacja „rozumowania” ma być, według Twardowskiego, sumą następujących podzbiorów: dedukcji, indukcji, konkludowania, redukcji, dowodzenia, sprawdzania, tłumaczenia, uzasadniania, wnioskowania, wyjaśniania (tłumaczenia), wyprowadzania itp. Dodatek ,itp.” wskazuje, że — być może — podana lista podzbiorów nie jest pełna. Ustalanie konotacji przebiega w ten sposób, że rozważane jest, klasa jakich przedmiotów jest wyznaczana przez kolejne warunki niezbędne bycia elementem denotacji definiowanego terminu.

Ostateczna definicja „rozumowania” przyjmuje u Twardowskiego następująca postać:

Rozumujemy zawsze i tylko, gdy dokonujemy czynności umysłowej polegającej na tym, że zarazem:

(a) wydajemy albo przynajmniej przedstawiamy sobie kolejno szereg co najmniej dwóch sądów, z których ostatni jest sądem dobieranym, a poprzednie - sądami danymi;

(b) między tymi sądami — a w szczególności między sądami danymi a sądem dobieranym — zachodzi jeden ze stosunków zależności logicznej, tj. przeciwieństwo, podprzeciwieństwo, wynikanie, odpowiedniość (scil. równoważność) (w jednym kierunku lub drugim), niezgodność (scil. sprzeczność) lub

\footnotetext{
${ }^{3}$ Zob. K. Twardowski, Co znaczy „doświadczalny” (1912), [w:] idem, Wybrane pisma..., s. 337-340.
} 
(c) stwierdzamy tak zwany logiczny wątek myśli, czyli to, że ten stosunek między sądami danymi a sądem dobieranym zachodzi.

Twardowski przy tym w następujący sposób zinterpretował wymienione stosunki zależności logicznej — idąc w ślad za Łukasiewiczem ${ }^{4}$. Oznaczmy sąd dany (resp. koniunkcję sądów danych) przez ' $\alpha$ ', a sąd dobierany — przez ' $\beta$ '. Wtedy:

(i) ' $\beta$ ' jest przeciwny względem ' $\alpha$ ', gdy jeżeli $\alpha$, to nie- $\beta$;

(ii) ' $\beta$ ' jest podprzeciwny względem ' $\alpha$ ', gdy jeżeli nie- $\alpha$, to $\beta$;

(iii) ' $\beta$ ' wynika z (dziś powiedzielibyśmy: jest implikowany materialnie przez) ' $\alpha$ ', gdy jeżeli $\alpha$, to $\beta$;

(iv) ' $\beta$ ' jest odpowiedni (dziś powiedzielibyśmy: równoważny) względem ' $\alpha$ ', gdy $\alpha$ zawsze i tylko, jeżeli $\beta$;

(v) ' $\beta$ ' jest niezgodny (dziś powiedzielibyśmy: sprzeczny) z ' $\alpha$ ', gdy $\alpha$ zawsze i tylko, jeżeli nie- $\beta$.

\section{Metoda indukcyjna}

Metodą indukcyjną Twardowski zajął się obszernie w Teorii badań indukcyjnych, którą wykładał w 1895 roku w Uniwersytecie Lwowskim. Sądzę, że to właśnie te wykłady stanowiły główną inspirację Łukasiewicza, który w dziesięcioleciu 1903-1913, a więc w okresie lwowskim, intensywnie zajmował się indukcją, a później, w okresie warszawskim, spowodował, że studia nad teorią indukcji podjęli uczniowie Twardowskiego (Czeżowski i Ajdukiewicz w latach pięćdziesiątych, a Kokoszyńska-Lutmanowa w pięćdziesiątych i sześćdziesątych) i Łukasiewicza (Hosiasson-Lindenbaumowa jeszcze w latach trzydziestych).

A. Indukcję sensu lato Twardowski charakteryzował następująco:

Indukcja w najobszerniejszym znaczeniu jest [...] rozumowaniem [...], za pomocą którego wnioskujemy, że to, co jest prawdą o poszczególnych jednostkach lub gatunkach, do jednego rodzaju należy: prawdą jest o całym rodzaju.

Są dwa rodzaje indukcji: wyczerpująca (zupełna) i niewyczerpująca (niezupełna), czyli indukcja właściwa. Różnicę między nimi najprościej jest przedstawić za pomocą schematów odpowiednich rozumowań.

Schemat indukcji wyczerpującej:

$A_{1}$ jest $B$.

$A_{2}$ jest $B$.

$\ldots$

$A_{\mathrm{k}}$ jest $B$.

Każde $A$ jest $A_{1}$ lub $A_{2}, \ldots$ lub $A_{\mathrm{k}}$.

Każde $A$ jest $B$.
Schemat indukcji niewyczerpującej:

$A_{1}$ jest $B$

$A_{2}$ jest $B$.

$\ldots$

$A_{\mathrm{k}}$ jest $B$.

Są $A$ nie będące ani $A_{1}$, ani $A_{2}, \ldots$ ani $A_{\mathrm{k}}$.

Każde $A$ jest $B$.

${ }^{4}$ Zob. K. Twardowski, O stosunkach logicznych (1904), [w:] idem, Logika i metafizyka. Miscellanea, Warszawa 1998, s. 97. 
Na pytanie, na czym polega wartość indukcji wyczerpującej, Twardowski odpowiedział:

Na zdobyciu twierdzenia ogólnego — podstawy dalszego wnioskowania albo działania praktycznego.

Na jakiej podstawie decydujemy się na indukcję właściwą (niewyczerpującą)? Według Twardowskiego tą podstawą jest hipoteza, że bądź $A$ jest przyczyną $B$, bądź $A$ i $B$ mają wspólną przyczynę. Akceptował tym samym Millowską zasadę, że:

Jeżeli A jest przyczyną B, wtedy wszędzie, gdzie A, tam B, [...] gdzie nie ma B, nie ma A, a każda zmiana w A łączyć się musi ze zmianą B.

Twardowski tak zdefiniował ,związek przyczynowy”:

$A$ - grupa pewnych okoliczności - jest przyczyną zjawiska $B$, gdy w tej samej chwili, w której $A$ staje się zupełna, scil. BEZPóśreDnio po zaistnieniu $A, B$ zaczyna istnieć z KONIECZNośCIĄ, scil. zawsze.

O wspomnianej hipotezie nie możemy twierdzić, że jest prawdziwa; jest ona jedynie mniej lub bardziej prawdopodobna. Przy tym:

Hipoteza jest tym prawdopodobniejsza:

(a) im większa jest liczba zgodnych z nią faktów;

(b) im większa jest RóżNORODNOŚĆ faktów z nią zgodnych;

(c) im mniej wymaga hipotez pomocniczych, aby stała się zgodna z faktami.

[Ponadto] prawd[opodobieństwo] hipotezy wzmaga się znacznie, gdy hipoteza da się przedstawić jako wynik hipotezy ogólniejszej już przedtem sprawdzonej.

Szczegółami zajmuje się teoria prawdopodobieństwa. I Twardowski przedstawił elementy rachunku prawdopodobieństwa w zakresie, który jest potrzebny do charakterystyki indukcji właściwej.

B. Przesłanki wnioskowania indukcyjnego — zarówno konstatacje szczegółowe, jak i przesłankę-hipotezę o związku przyczynowym — zdobywamy w nauce dwoma sposobami: poprzez obserwację i poprzez eksperyment.

Twardowski określił obserwację następująco:

Obserwacja [...] [jest to] SzEREG spostrzeżeń dokonanych z uwagą nad pewnym zjawiskiem odnoszących się tak do całości, jako też do poszczególnych jego części.

Obserwacja powinna być wierna (a więc ,nic więcej nie uważa się za obserwowane, ponad to, co spostrzeżenia podają") i wyczerpująca (a więc ,nie przeoczyło się żadnej części obserwowanego zjawiska”). Opis obserwowanego zjawiska zawsze przekracza to, co zostało zaobserwowane: wymaga bowiem dokonania interpretacji i klasyfikacji (przez to, że narzędziem opisu jest język).

Eksperyment uważał Twardowski za „obserwację zjawiska dokonaną po dowolnie zmienionych okolicznościach tego zjawiska". Główną trudnością związaną z eksperymentami jest to, że — podobnie jak obserwacje — nigdy nie mogą być one w pełni wyczerpujące ze względu na ogromną liczbę kombinacji okoliczności, które trzeba uwzględnić (a wchodzi tu w grę ich usunięcie lub zmiana).

C. Jak wiadomo - metoda ustalania, czy między zjawiskami zachodzi związek przyczynowy, została opisana przez Bacona, a następnie skorygowana przez Her- 
schela i Milla oraz Whewella, Duhamela, Jevonsa i Sigwarta. Według Twardowskiego zarzuty przez nich podniesione upadają, jeśli wyraźnie odróżni się „dochodzenie do wyniku” od „usprawiedliwiania wyniku”: badania indukcyjne, które mają prowadzić do postawienia hipotezy o związku przyczynowym — od postępowania uzasadniającego gotową hipotezę. Metoda Bacona-Milla dotyczy tego pierwszego - nie zaś tego drugiego.

Ogólnie badanie indukcyjne Twardowski opisał następująco:

Mamy [...] w badaniu indukcyjnym cztery kroki:

(a) skonstatowanie pewnych faktów;

(b) dobieranie przesłanek wyższych, czyli stawianie hipotez względem praw, pod które by fakty te dały się podciągnąć;

(c) dedukcja [nowych zdań faktualnych];

(d) sprawdzanie.

Obserwacja i eksperyment znajdują zastosowanie jedynie w kroku (a) i (d). Wbrew Baconowi i jego tradycji - a zgodnie z faktami z historii nauki — do postawienia hipotezy nie trzeba gromadzić wielkiej liczby faktów. Niestety nie ma prawideł stawiania hipotez. Można jedynie, zdaniem Twardowskiego, podać warunki negatywne. Brzmią one tak:

(a) Hipoteza, którą stawiamy, musi być taka, aby można uczynić na jej podstawie dedukcję prowadzącą do wyników, które dałyby się porównać z faktami.

(b) Hipoteza nie śmie stawać w sprzeczności z prawami umysłu (logicznymi) lub z prawami przyrody, jak długo prawa te musimy uważać za słuszne.

(c) Wyniki dedukowane z hipotezy muszą się zgadzać z faktami.

W warunku (a) chodzi o to, żeby zjawisko uznane w hipotezie za przyczynę ,posiadało znane nam skądinąd właściwości”. Interwencja Boga na przykład nie spełniałaby warunku (a), gdybyśmy skądinąd niczego o Bogu nie wiedzieli. Ogólnie:

Stwarzając hipotezę, że przyczyną szeregu zjawisk $[N]$ jest zjawisko $M$, musimy mieć przypisane $[\ldots]$ zjawisku $[M]$ właściwości, aby wiedzieć, jak [...] [zjawisko $M]$ działa, jeśli [zjawisko $M]$ wpływ wywiera [na szereg zjawisk $N]^{5}$.

Warunek (b) w odniesieniu do praw umysłu (logiki) jest absolutny, ale w odniesieniu do praw przyrody już nie, gdyż żadne prawo przyrody nie jest pewne.

Twardowski odrzucił natomiast stawiany przez niektórych (w tradycji Hobbesa) warunek, aby stawiane hipotezy były zrozumiałe; uważał bowiem, że zrozumiałość jest kwestią subiektywną, o czym świadczą fakty z historii nauki.

D. Twardowski kładł nacisk na odróżnienie praw empirycznych od praw przyczynowych. Prawa empiryczne konstatują jedynie stały związek między pewnymi zjawiskami. Są one odpowiedzią na pytanie, jaki jest ów stały związek. Na pytanie, dlaczego ów stały związek ma miejsce, odpowiadają prawa przyczynowe. Związek, o którym mówi prawo empiryczne, jest istotnie związkiem stałym, tylko gdy jest on związkiem koniecznym, a to znaczy, że w jego tle stoi związek przyczynowo-skutkowy. Oto słowa Twardowskiego:

\footnotetext{
${ }^{5}$ Cytat pochodzi z Indukcji w metafizyce.
} 
Jeżeli [...] chcemy upewnić się co do ważności powszechnej prawa empirycznego, musimy wykazać, że jednostajność w połączeniu zjawisk, wypowiedziana w prawie empirycznym, wynika ze związku przyczynowego między zjawiskami - czyli: musimy prawo empiryczne sprowadzić do prawa przyczynowego.

Faktom, podpadajacym pod wykryte prawo przyczynowe, prawo to dostarcza wytłumaczenia.

E. Twardowski zajął też stanowisko wobec zagadnienia, które dziś znane jest jako możliwość teorii wszystkiego. Oto jego pogląd w tej sprawie:

[W nauce staramy się prawa] [spro]wadzać do coraz ogólniejszych. Czy możemy mieć nadzieję sprowadzenia WSZYSTKICH do jednego prawa ogólnego? [...] Na to potrzeba, aby wszystkie warunki dały się podciągnąć pod jedno prawo. Ale, rzecz jasna, że to [jest] niemożliwe.

\section{Indukcja w metafizyce}

Twardowski już u progu swojej drogi twórczej — bo w 1897 roku — zadał sobie pytanie, „dlaczego metoda indukcyjna, stosowana z tak wielkim pożytkiem w naukach przyrodniczych, nie wydała dotąd równie zadowalających rezultatów w metafizyce". Jego odpowiedź brzmiała:

Twórcy hipotez metafizycznych nie przestrzegają zazwyczaj koniecznych warunków, od spełnienia których zawisła możność sprawdzenia lub odrzucenia jakichkolwiek hipotez.

Po pierwsze, niektóre hipotezy metafizyczne zawierają sprzeczności. Jako przykład Twardowski podał tak zwaną hipotezę ślepej woli Schopenhauera.

Po drugie:

Prawie wszystkie inne hipotezy grzeszą albo brakiem ścisłego i jasno określonego sformułowania, albo tym, że operują przyczynami o nieznanym nam zupełnie sposobie działania, albo i jednym, i drugim.

Do takich hipotez Twardowski zaliczył hipotezy: (a) że świat jest celowo urządzony; (b) że kształt świata jest efektem ,ślepej konieczności”; (c) że dusza jest substancją prostą.

Po trzecie, bywa zazwyczaj, że nawet jeśli hipoteza zostanie sprecyzowana tak, iż da się z niej wydedukować twierdzenia faktualne, to okazuje się, że nie sposób stwierdzić zgodności lub niezgodności tych twierdzeń z faktami. Tu jako przykłady Twardowski podał hipotezy optymizmu i pesymizmu oraz hipoteze panpsychizmu.

Ocenę tę podzielała większość przedstawicieli Szkoły Lwowsko-Warszawskiej na czele z Łukasiewiczem (1915).

Potrzeba posiadania całościowego „poglądu na świat” jest — według Twardowskiego - nieusuwalna. Droga do naukowej metafizyki jest jednak daleka. Co w tej sytuacji robić? Trzeba się tymczasowo zadowolić światopoglądem nienaukowym: na przykład religijnym, ponieważ — jak wyrażał się Twardowski — „człowiek nie tylko rozumem” stoi. I w oryginalny sposób uzasadniał racjonalność oparcia się na takich nienaukowych światopoglądach. Przyjęcie ich byłoby nieracjonalne, gdyby były one sprzeczne ze światopoglądem naukowym. Ale nie możemy uważać ich za sprzeczne ze światopoglądem naukowym, gdyż takiego światopoglądu jeszcze nie ma. 


\section{Bibliografia}

Popper K., Logik der Forschung, Wien 1935.

Twardowski K., Co znaczy „doświadczalny” (1912), [w:] idem, Wybrane pisma filozoficzne, Warszawa 1965.

Twardowski K., O stosunkach logicznych (1904), [w:] idem, Logika i metafizyka. Miscellanea, Warszawa 1998.

Twardowski K., Symbolomania i pragmatofobia (1912), [w:] idem, Wybrane pisma filozoficzne, Warszawa 1965.

\section{Kazimierz Twardowski's contribution to the evolution of logic in Poland}

\section{Summary}

Twardowski's legacy, which has been published so far - and the detailed analysis of it - suffices to consider him a classic of Polish semiotics. The published results of Twardowski in the field of methodology also deserve high scores. A new light on the contribution of Twardowski to the development of logic in Poland sheds the content of his unpublished legacy, including the content of his lectures on logic and unedited logical monographs. Firstly, Twardowski conducted fruitful research on many methodological problems. The result of this research was - an unknown to a wider audience - a new approach to the theory of induction and an original sketch of the perspectives of the inductive method in metaphysics, the first in our literature such a comprehensive monograph on reasoning and reconstruction of the concept of understanding. Secondly, Twardowski referred in his unpublished lectures and monographs to the important results of the nineteenth-century formal logic, thus giving their students an important impulse for individual research in this field. In this text, I focus my attention on the logical issues raised by Twardowski just in his unpublished texts.

Keywords: algebraic logic, deduction, induction, logical symbolism, syllogistics, traditional logic, Twardowski 